\title{
Analisis Pengukuran Kinerja Aliran Supply Chain di PT. Asia Forestama Raya dengan Metode Supply Chain Operation Reference (SCOR)
}

\author{
Misra Hartati ${ }^{1}$, Dina Efendi ${ }^{2}$, Melfa Yola $^{3}$ \\ Jurusan Teknik Industri, Fakultas Sains dan Teknologi, UIN Sultan Syarif Kasim Riau \\ Jl. HR. Soebrantas No. 155 Simpang Baru, Panam, Pekanbaru, 28293 \\ Email: me.dinaefendi@gmail.com
}

\begin{abstract}
ABSTRAK
PT. Asia Forestama Raya (AFR) adalah perusahaan yang memproduksi plywood (kayu lapis). Permasalahan yang sering dihadapi perusahaan antara lain, keterlambatan bahan baku, jumlah bahan baku yang tidak sesuai dengan permintaan, dan keterlambatan pengiriman produk. Dengan permasalahan yang terjadi di sepanjang aliran supply chain perlu dilakukan pengukuran kinerja aliran supply chain menggunakan metode Supply chain Operation Reference (SCOR). Pengukuran dilakukan dengan beberapa tahapan yaitu identifikasi matrik SCOR, verifikasi Key Performance Indicator (KPI) dengan menyebarkan kuesioner indikator, perhitungan nilai normalisasi (skor), pembobotan KPI menggunakan metode Analytical Hierarchy Process (AHP) dengan menyebarkan kuesioner AHP. Nilai kinerja aliran supply chain yang didapatkan adalah 73,33 dengan kategori Good, dimana kinerja terendah terdapat pada proses source yaitu 69,29 dengan kategori Average.
\end{abstract}

Kata Kunci: AHP, Kinerja Supply chain, Supply chain Operation Reference (SCOR)

\section{Pendahuluan}

Perusahaan untuk dapat bertahan dalam perkembangan dan perubahan kondisi pasar perlu meningkatkan kinerja perusahaan. Kinerja perusahaan merupakan tingkat pencapaian hasil dalam rangka mewujudkan tujuan perusahaan. Pada umumnya, tujuan utama dari setiap perusahaan yaitu memenangkan persaingan, meningkatkan customer service serta mendapatkan keuntungan (profit). Supply chain Management digunakan untuk dapat menyatukan seluruh kegiatan produksi sehingga sesuai dengan rencana produksi.

PT. Asia Forestama Raya (AFR) merupakan perusahaan yang mengolah hasil hutan (kayu) menjadi kayu lapis atau plywood. PT. AFR telah berdiri sejak tahun 1974 di Besitang. Saat ini PT. AFR bertempat di tepian Sungai Siak, Kelurahan Limbungan, Kecamatan Rumbai Pesisir, Kota Pekanbaru, Riau. Produk yang dihasilkan oleh PT. AFR adalah plywood dengan berbagai ukuran untuk memenuhi bermacam-macam kebutuhan, baik untuk pasar ekspor maupun lokal.

Dalam produksi plywood dibutuhkan bahan baku yang didatangkan dari beberapa supplier.

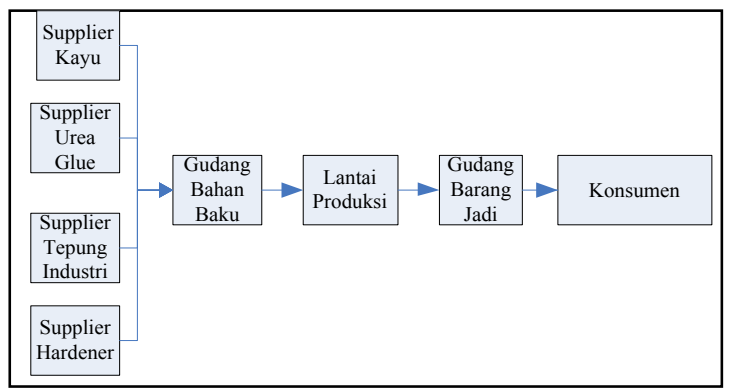

Gambar 1. Aliran rantai pasok PT AFR

Proses produksi plywood secara umum dimulai dari proses pemotongan kayu atau log (chain saw), pengupasan balok kayu (rotary), pengeringan (dryer), penyambungan (composing), perekatan (glue spreader), Pengepresan (hot and cold press), perakitan dan terakhir proses finishing. Setelah selesai proses produksi, plywood akan di inspeksi atau diperiksa kualitasnya oleh bagian Quality control. Proses selanjutnya adalah melakukan pengepakan dan pengiriman kepada konsumen baik untuk lokal maupun luar negeri.

Terdapat beberapa permasalahan yang terjadi pada kegiatan supply chain yang ada di PT. AFR diantaranya adalah masalah keterlambatan bahan baku dan jumlah bahan baku yang 
tidak sesuai dengan yang dipesan. Hal ini merupakan salah satu faktor yang menyebabkan terganggunya proses produksi dan tidak tercapainya target produksi yang telah ditetapkan. Berikut Rekapitulasi data pemesanan bahan baku dari bulan Agustus 2014-Juli 2015.

Tabel 1 Rekapitulasi Data Pemesanan Bahan Baku Kayu Agust Agustus 2014-Juli 2015

\begin{tabular}{|c|c|c|c|c|c|}
\hline No & $\begin{array}{c}\text { Tanggal } \\
\text { Order }\end{array}$ & $\begin{array}{c}\text { Lead } \\
\text { time } \\
\text { (hari) }\end{array}$ & $\begin{array}{c}\text { Tanggal } \\
\text { Penerimaan }\end{array}$ & $\begin{array}{c}\text { Jumlah } \\
\text { Pemesana } \\
\mathbf{n}_{\left(\mathbf{m}^{\mathbf{3}} \mathbf{)}\right.}\end{array}$ & $\begin{array}{c}\text { Jumlah } \\
\text { Penerima } \\
\text { an }\end{array}$ \\
\hline 1 & $12 / 8 / 2014$ & 21 & $1 / 9 / 2014$ & $17.144,00$ & $17.144,0$ \\
\hline 2 & $15 / 10 / 2014$ & 17 & $1 / 11 / 2014$ & $18.340,30$ & $18.340,3$ \\
\hline 3 & $10 / 12 / 2014$ & 14 & $24 / 12 / 2014$ & $15.213,70$ & $15.213,7$ \\
\hline 4 & $13 / 2 / 2015$ & 32 & $17 / 03 / 2015$ & $16.240,20$ & $16.240,2$ \\
\hline 5 & $12 / 5 / 2015$ & 14 & $26 / 05 / 2015$ & $15.352,90$ & $15.352,9$ \\
\hline 6 & $12 / 7 / 2015$ & 14 & $26 / 07 / 2015$ & $17.822,10$ & $17.822,1$ \\
\hline
\end{tabular}

Tabel 2 Rekapitulasi Data Pemesanan Bahan Baku Urea glue Agustus 2014 - Juli 2015

\begin{tabular}{|c|c|c|c|c|c|}
\hline No & $\begin{array}{c}\text { Tanggal } \\
\text { order }\end{array}$ & $\begin{array}{c}\text { Lead } \\
\text { time } \\
\text { (hari) }\end{array}$ & $\begin{array}{c}\text { Tanggal } \\
\text { penerimaan }\end{array}$ & $\begin{array}{c}\text { Jumlah } \\
\text { pemesan } \\
\text { an (kg) }\end{array}$ & $\begin{array}{c}\text { Jumlah } \\
\text { penerim } \\
\text { aan (kg) }\end{array}$ \\
\hline 1 & $12 / 8 / 2014$ & 5 & $17 / 8 / 2014$ & 5.000 & 5.000 \\
\hline 2 & $12 / 9 / 2014$ & 5 & $17 / 9 / 2014$ & 4.500 & 4.500 \\
\hline 3 & $13 / 10 / 2014$ & 6 & $19 / 10 / 2041$ & 6.200 & 6.200 \\
\hline 4 & $12 / 11 / 2014$ & 7 & $19 / 11 / 2014$ & 3.450 & 3.450 \\
\hline 5 & $12 / 12 / 2014$ & 12 & $24 / 12 / 2014$ & 4.550 & 4.550 \\
\hline 6 & $12 / 1 / 2015$ & 7 & $19 / 1 / 2015$ & 3.250 & 3.250 \\
\hline 7 & $12 / 2 / 2015$ & 6 & $18 / 2 / 2015$ & 6.500 & 6.500 \\
\hline 8 & $12 / 3 / 2015$ & 5 & $17 / 3 / 2015$ & 5.700 & 5.700 \\
\hline 9 & $13 / 4 / 2015$ & 6 & $19 / 4 / 2015$ & 6.400 & 6.400 \\
\hline 10 & $12 / 5 / 2015$ & 9 & $21 / 5 / 2015$ & 7.200 & 7.200 \\
\hline 11 & $12 / 6 / 2015$ & 5 & $17 / 6 / 2015$ & 4.450 & 4.450 \\
\hline 12 & $13 / 7 / 2015$ & 10 & $23 / 7 / 2015$ & 4.650 & 4.650 \\
\hline
\end{tabular}

Tabel 3 Rekapitulasi Data Pemesanan Bahan Baku Tepung Industri Agustus 2014 - Juli 2015

\begin{tabular}{|c|c|c|c|c|c|}
\hline $\begin{array}{c}\text { Tanggal } \\
\text { order }\end{array}$ & $\begin{array}{c}\text { LT } \\
\text { (hr) }\end{array}$ & $\begin{array}{c}\text { Tanggal } \\
\text { terima }\end{array}$ & $\begin{array}{c}\text { Jml } \\
\text { peasn } \\
(\mathbf{k g})\end{array}$ & $\begin{array}{c}\text { Jml } \\
\text { terima }\end{array}$ & Ket \\
\hline $14 / 8 / 2014$ & 3 & $17 / 8 / 2014$ & 15.000 & 15.000 & Lengkap \\
\hline $15 / 9 / 2014$ & 3 & $18 / 9 / 2014$ & 12.000 & 10.000 & Kurang \\
\hline $14 / 10 / 2014$ & 3 & $17 / 10 / 2014$ & 12.500 & 12.500 & Lengkap \\
\hline $14 / 11 / 2014$ & 3 & $17 / 11 / 2014$ & 13.500 & 13.500 & Lengkap \\
\hline $15 / 12 / 2014$ & 3 & $18 / 12 / 2014$ & 11.100 & 11.100 & Lengkap \\
\hline $14 / 1 / 2015$ & 3 & $17 / 1 / 2015$ & 12.500 & 12.000 & Kurang \\
\hline $13 / 2 / 2015$ & 3 & $16 / 2 / 2015$ & 12.000 & 9.580 & Kurang \\
\hline $13 / 3 / 2015$ & 3 & $16 / 3 / 2015$ & 14.000 & 14.000 & Lengkap \\
\hline $14 / 4 / 2015$ & 3 & $17 / 4 / 2015$ & 13.500 & 13.500 & Lengkap \\
\hline $14 / 5 / 2015$ & 3 & $17 / 5 / 2015$ & 11.500 & 10.000 & Kurang \\
\hline $15 / 6 / 2015$ & 3 & $18 / 6 / 2015$ & 14.300 & 12.550 & Kurang \\
\hline $14 / 7 / 2015$ & 3 & $17 / 7 / 2015$ & 15.100 & 14.230 & Kurang \\
\hline
\end{tabular}

Tabel 4 Rekapitulasi Data Permintaan Bahan Baku Hardener Agustus 2014 - Juli 2015

\begin{tabular}{|c|c|c|c|c|c|c|}
\hline No & $\begin{array}{c}\text { Tanggal } \\
\text { order }\end{array}$ & $\begin{array}{c}\text { Lead } \\
\text { time } \\
\text { (hari) }\end{array}$ & $\begin{array}{c}\text { Tanggal } \\
\text { penerimaan }\end{array}$ & $\begin{array}{c}\text { Jumlah } \\
\text { pemesanan } \\
\text { (Lt) }\end{array}$ & $\begin{array}{c}\text { Jumlah } \\
\text { penerimaan } \\
(\mathbf{L t})\end{array}$ & Ket \\
\hline 1 & $14 / 8 / 2014$ & 2 & $16 / 8 / 2014$ & 500 & 500 & Lengkap \\
\hline 2 & $15 / 9 / 2014$ & 2 & $17 / 9 / 2014$ & 400 & 400 & Lengkap \\
\hline 3 & $14 / 10 / 2014$ & 2 & $16 / 10 / 2014$ & 350 & 250 & Kurang \\
\hline 4 & $14 / 11 / 2014$ & 3 & $17 / 11 / 2014$ & 650 & 650 & Lengkap \\
\hline 5 & $15 / 12 / 2014$ & 2 & $17 / 12 / 2014$ & 400 & 400 & Lengkap \\
\hline 6 & $14 / 1 / 2015$ & 2 & $17 / 1 / 2015$ & 400 & 400 & Lengkap \\
\hline 7 & $13 / 2 / 2015$ & 2 & $15 / 2 / 2015$ & 450 & 300 & Kurang \\
\hline 8 & $13 / 3 / 2015$ & 2 & $15 / 3 / 2015$ & 450 & 450 & Lengkap \\
\hline 9 & $14 / 4 / 2015$ & 2 & $16 / 4 / 2015$ & 400 & 400 & Lengkap \\
\hline 10 & $14 / 5 / 2015$ & 2 & $16 / 5 / 2015$ & 550 & 550 & Lengkap \\
\hline 11 & $15 / 6 / 2015$ & 2 & $17 / 6 / 2015$ & 400 & 400 & Lengkap \\
\hline 12 & $14 / 7 / 2015$ & 2 & $16 / 7 / 2015$ & 450 & 450 & Lengkap \\
\hline
\end{tabular}

Lead time yang telah ditetapkan perusahaan untuk bahan baku kayu adalah 14 hari. Pada Tabel 1 lead time pada pemesanaan 15/10/2014 selama 17 hari, pada pemesanan 12-8-2014 selama 21 hari dan pada pemesanan 13-2-2015 selama 32 hari, keterlambatan terjadi dikarenakan supplier sulit mendapatkan bahan baku serta kesalahan teknis pada saat proses pengiriman. Pada Tabel 2 menunjukkan jumlah pemesanan untuk urea glue. lead time pada pemesanan 12-12-2014 selama 12 hari , 12-5-2015 selama 9 hari, dan 13-7-2015 selama 10 hari. Hal ini tidak sesuai dengan lead time yang ditetapkan perusahaan yaitu selama 5-7 hari kerja.

Tabel 3 menujukkan jumlah pemesanan tepung industri yang diterima tidak sesuai dengan yang dipesan, hal ini dapat dilihat pada no $2,6,7,10,11$, dan 12. Ketidaksesuaian jumlah barang yang diterima dengan yang dipesan disebabkan oleh stok barang yang ada pada supplier tidak mencukupi, sehingga mereka hanya mengirim barang yang tersedia di gudang. Untuk bahan baku harderner Tabel 4, jumlah barang yang tidak sesuai terjadi pada no 3 dan 7 .

Permasalahan keterlambatan dan jumlah bahan baku yang diterima tidak sesuai dengan pemesanan yang telah diuraikan di atas merupakan salah satu faktor yang menyebabkan terganggunya proses produksi sehingga tidak tercapainya target produksi yang telah ditetapkan perusahaan setiap bulannya. Penetapan target produksi dilakukan oleh perusahaan untuk menjaga ketersediaan barang di gudang (safety stock), sehingga ketika terdapat permintaan yang 
dilakukan dalam waktu dekat dapat terpenuhi. Selain itu, safety stock juga digunakan untuk memenuhi permintaan ketika jumlah produksi yang ada tidak mencukupi.

Tabel 5 Rekapitulasi Data Produksi Plywood Agustus (2014)Juli (2015) PT. AFR

\begin{tabular}{|c|c|c|c|c|c|c|}
\hline Bulan & $\begin{array}{l}\text { Produ } \\
\text { ksi } \\
\text { Bersih } \\
\left(\mathbf{m}^{3}\right)\end{array}$ & $\begin{array}{l}\text { Targ } \\
\text { et } \\
\text { Prod } \\
\text { uksi } \\
\left(\mathbf{m}^{3}\right) \\
\end{array}$ & $\begin{array}{c}\text { Selisih } \\
\text { Jumlah } \\
\text { Produksi }\end{array}$ & $\begin{array}{c}\text { Harga } \\
\text { Produk/ } \\
\text { m }^{3}(\mathbf{R p})\end{array}$ & $\begin{array}{c}\text { Jumlah Harga } \\
\text { Selisih Produksi } \\
\text { (Rp) }\end{array}$ & $\begin{array}{l}\text { cukup tinggi. Hal ini tentunya juga mengganggu } \\
\text { kelancaran dari aliran supply chain yang ada di PT. } \\
\text { AFR. Dengan adanya cacat mengakibatkan produk } \\
\text { turun grade sehingga perusahaan harus menambah }\end{array}$ \\
\hline Agustus & $4.072,0$ & 5.200 & $-1.127,99$ & 4.189 .705 & -4.725 .945 .343 & jumlah produksi agar kekurangan produk dap \\
\hline September & $5.259,0$ & 5.200 & 59,06 & 4.189 .705 & $247.443 .977,3$ & 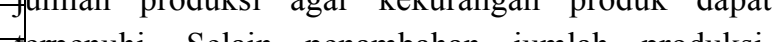 \\
\hline Oktober & $4.526,2$ & 5.200 & $-673,71$ & 4.189 .705 & -2.822 .646 .156 & terpenuhi. Selain p \\
\hline November & $4.430,4$ & 5.200 & $-769,58$ & 4.189 .705 & -3.224 .313 .174 & perusahaan juga harus melakukan beberapa treatment \\
\hline Desember & $5.409,4$ & 5.200 & 209,46 & 4.189 .705 & $877.575 .609,3$ & t \\
\hline Januari & $4.152,9$ & 5.200 & $-1.047,04$ & 4.189 .705 & -4.386 .788 .723 & 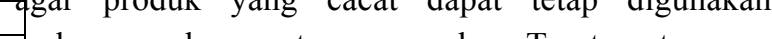 \\
\hline Februari & $4.014,6$ & 5.200 & $-1.185,37$ & 4.189 .705 & -4.966 .350 .616 & walaupun harus turun grade. \\
\hline Maret & $4.377,4$ & 5.200 & $-822,57$ & 4.189 .705 & -3.446 .325 .642 & dilakukan menyebabkan waktu produksi menjadi \\
\hline April & $4.687,5$ & 5.200 & $-512,47$ & 4.189 .705 & -2.147 .098 .121 & \\
\hline Mei & $4.582,3$ & 5.200 & $-617,61$ & 4.189 .705 & -2.587 .603 .705 & \\
\hline Juni & $4.649,1$ & 5.200 & $-550,86$ & 4.189 .705 & -2.307 .940 .896 & cacatan yang ter \\
\hline Juli & $3.904,3$ & 5.200 & $-1.295,64$ & 4.189 .705 & -5.428 .349 .386 & Agustus 2014 - Juli 2015 ditampilkan pada Tabel 6. \\
\hline Total & $\begin{array}{c}54.065 \\
68 \\
\end{array}$ & & $-7.038,68$ & & -34.918 .342 .176 & \\
\hline
\end{tabular}

Tabel 6 Rekapitulasi Data Cacat Agustus (2014) - Juli (2015) PT. AFR

\begin{tabular}{|c|l|c|c|c|c|c|c|c|}
\hline \multirow{2}{*}{ No } & \multirow{2}{*}{$\begin{array}{c}\text { Bulan } \\
\text { Produksi }\end{array}$} & $\mathbf{6 - 1}$ & $\mathbf{C - 2}$ & $\mathbf{C - 3}$ & $\mathbf{C - 4}$ & $\mathbf{C - 5}$ & $\mathbf{C - 6}$ & $\begin{array}{c}\text { Total } \\
\text { Kecacatan } \\
\text { (Pcs) }\end{array}$ \\
\cline { 3 - 9 } & & $\mathbf{C r i t e r i a}$ Kecacatan & 1.176 \\
\hline 1 & Agustus & 276 & 1.622 & 2.032 & 1.737 & 1.919 & 249 & 16.172 \\
\hline 2 & September & 153 & 900 & 1.128 & 964 & 1.065 & 32 & 12.077 \\
\hline 3 & Oktober & 294 & 1.729 & 2.166 & 1.851 & 2.046 & 61 & 12.389 \\
\hline 4 & November & 569 & 2.094 & 2.623 & 2.242 & 2.477 & 0 & 18.152 \\
\hline 5 & Desember & 85 & 499 & 625 & 535 & 591 & 18 & 12.358 \\
\hline 6 & Januari & 353 & 2.072 & 2.596 & 2.219 & 2.452 & 74 & 12.119 \\
\hline 7 & Februari & 735 & 4.316 & 5.407 & 4.622 & 5.106 & 0 & 29.952 \\
\hline 8 & Maret & 624 & 3.665 & 4.592 & 3.925 & 4.337 & 130 & 37.459 \\
\hline 9 & April & 231 & 1.359 & 1.702 & 1.455 & 1.608 & 49 & 23.677 \\
\hline 10 & Mei & 453 & 2.662 & 3.336 & 2.851 & 3.150 & 94 & 18.950 \\
\hline 11 & Juni & 341 & 2.003 & 2.509 & 2.145 & 2.370 & 72 & 21.986 \\
\hline 12 & Juli & 471 & 1.733 & 2.171 & 1.855 & 2.050 & 61 & 8.341 \\
\hline & Total & $\mathbf{4 . 5 8 5}$ & $\mathbf{2 4 . 6 5 4}$ & $\mathbf{3 0 . 8 8 7}$ & $\mathbf{2 6 . 4 0 1}$ & $\mathbf{2 9 . 1 7 1}$ & $\mathbf{8 4 0}$ & $\mathbf{2 2 3 . 6 3 6}$ \\
\hline
\end{tabular}

Dari Tabel 5 dapat dilihat bahwa perusahaan mengalami kerugian sebesar Rp 34.918.342.176 akibat target produksi yang tidak tercapai. Selain keterlambatan bahan baku, faktor lain yang menyebabkan tidak terpenuhinya target produksi perusahaan adalah tingkat kecacatan yang terjadi ukup tinggi. Hal ini tentunya juga mengganggu kelancaran dari aliran supply chain yang ada di PT. AFR. Dengan adanya cacat mengakibatkan produk turun grade sehingga perusahaan harus menambah 
Keterangan :

\begin{tabular}{|c|c|}
\hline C-1 : & Core Tidak Rata \\
\hline C-2 : & $\begin{array}{l}\text { Face Tidak Baik / } \\
\text { Kurang }\end{array}$ \\
\hline C-3: & $\begin{array}{l}\text { Core Tidak Baik / } \\
\text { Tipis }\end{array}$ \\
\hline C-4 : & Core kurang / kosong \\
\hline $\mathrm{C}-5$ & Salah Potong \\
\hline C-6 & Cekung \\
\hline
\end{tabular}

Perusahaan berusaha untuk dapat memenuhi permintaan konsumen dengan memberikan kualitas yang baik dan tepat waktu dalam pengiriman. Tetapi permasalahan yang telah diuraikan sebelumnya juga menyebabakan terjadinya beberapa keterlambatan dalam pengiriman plywood. Hal ini tentunya menyebabkan

beberapa konsumen memberikan komplain terhadap pihak perusahaan.

Dengan adanya permasalahan pada aliran supply chain tersebut, maka perlu dilakukannya penelitian mengenai kinerja aliran Supply chain di PT. Asia Forestama Raya. Pengukuran kinerja aliran supply chain yang dilakukan pada penelitian sebelumnya antara lain dengan menggunakan metode Balance scorecard dan metode POA (Performance Of Activity) yang hanya menggambarkan kondisi internal perusahaan saja. Penelitian ini menggunakan metode SCOR (Supply chain Operation Reference) dimana dapat menggambarkan dan mengidentifikasi permasalahan supply chain secara menyeluruh. Model SCOR dapat menggambarkan setiap permasalahan supply chain yang terjadi mulai dari supplier, proses produksi hingga produk sampai pada konsumen akhir dengan melihat 5 proses penting yaitu plan, source, make, deliver, dan return.

Maka permasalahan yang dapat dirumuskan adalah 'Bagaimana mengukur kinerja aliran supply chain PT. AFR dengan menggunakan metode SCOR dan dimensi mana saja yang menjadi prioritas untuk dilakukan perbaikan?"

\section{Metodologi Penelitian}

Pada bab ini akan diuraikan metodologi penelitian atau tahap-tahap penelitian yang akan dilalui dari awal sampai akhir. Pada penelitian ini, tahap-tahap yang akan dilakukan adalah :

\begin{tabular}{|c|c|c|}
\hline $\begin{array}{c}\text { Proses } \\
\text { (Level 1) }\end{array}$ & $\begin{array}{l}\text { Dimensi } \\
\text { (Level 2) }\end{array}$ & $\begin{array}{c}\text { Key Performance Indicator } \\
\text { (Level 3) }\end{array}$ \\
\hline \multirow{5}{*}{ Plan } & \multirow{5}{*}{$\begin{array}{l}\text { Responsive } \\
\text { ness }\end{array}$} & Perencanaan kebutuhan bahan baku \\
\hline & & Perencanaan distribusi \\
\hline & & $\begin{array}{l}\text { Waktu yang dibutuhkan untuk proses } \\
\text { perencanaan }\end{array}$ \\
\hline & & waktu mengidentifikasi produk baru \\
\hline & & Perencanaan proses pengadaan bahan baku \\
\hline \multirow{4}{*}{ Source } & \multirow[b]{2}{*}{ Reliability } & Pemenuhan bahan baku yang sempurna \\
\hline & & $\begin{array}{l}\text { Kehandalan supplier dalam pengiriman } \\
\text { bahan baku }\end{array}$ \\
\hline & $\begin{array}{l}\text { Responsive } \\
\text { ness }\end{array}$ & Waktu siklus untuk pemenuhan bahan baku \\
\hline & Agility & Penanganan bahan baku yang cacat \\
\hline \multirow{7}{*}{ Make } & \multirow{3}{*}{ Reliability } & Penanganan produk cacat atau turun grade \\
\hline & & Penyelesaian produksi sesuai jadwal \\
\hline & & $\begin{array}{l}\text { Ketanggapan memproduksi pesanan } \\
\text { konsumen yang bervariasi }\end{array}$ \\
\hline & \multirow{4}{*}{ Agility } & Penanganan kerusakan mesin produksi \\
\hline & & Fleksibilitas produksi \\
\hline & & Jumlah produk cacat \\
\hline & & Kinerja karyawan \\
\hline \multirow{5}{*}{ Deliver } & Reliability & Kualitas pengiriman produk \\
\hline & \multirow{2}{*}{$\begin{array}{l}\text { Responsiv } \\
\text { eness }\end{array}$} & Pengiriman produk tepat waktu \\
\hline & & Jumlah pengiriman bahan baku yang tepat \\
\hline & \multirow{2}{*}{ Agility } & $\begin{array}{l}\text { Fleksibilitas pengiriman terhadap } \\
\text { penurunan permintaan }\end{array}$ \\
\hline & & $\begin{array}{l}\text { Fleksibilitas pengiriman terhadap } \\
\text { peningkatan permintaan }\end{array}$ \\
\hline \multirow{4}{*}{ Return } & Reliability & Jumlah komplain dari konsumen \\
\hline & \multirow{3}{*}{$\begin{array}{l}\text { Responsiv } \\
\text { eness }\end{array}$} & $\begin{array}{l}\text { Persentasi penggantian produk cacat } \\
\text { dengan kuantitas dan jenis yang tepat }\end{array}$ \\
\hline & & $\begin{array}{l}\text { Penanganan dari komplain yang diajukan } \\
\text { konsumen }\end{array}$ \\
\hline & & $\begin{array}{l}\text { Waktu tunggu penggantian produk yang } \\
\text { rusak }\end{array}$ \\
\hline
\end{tabular}




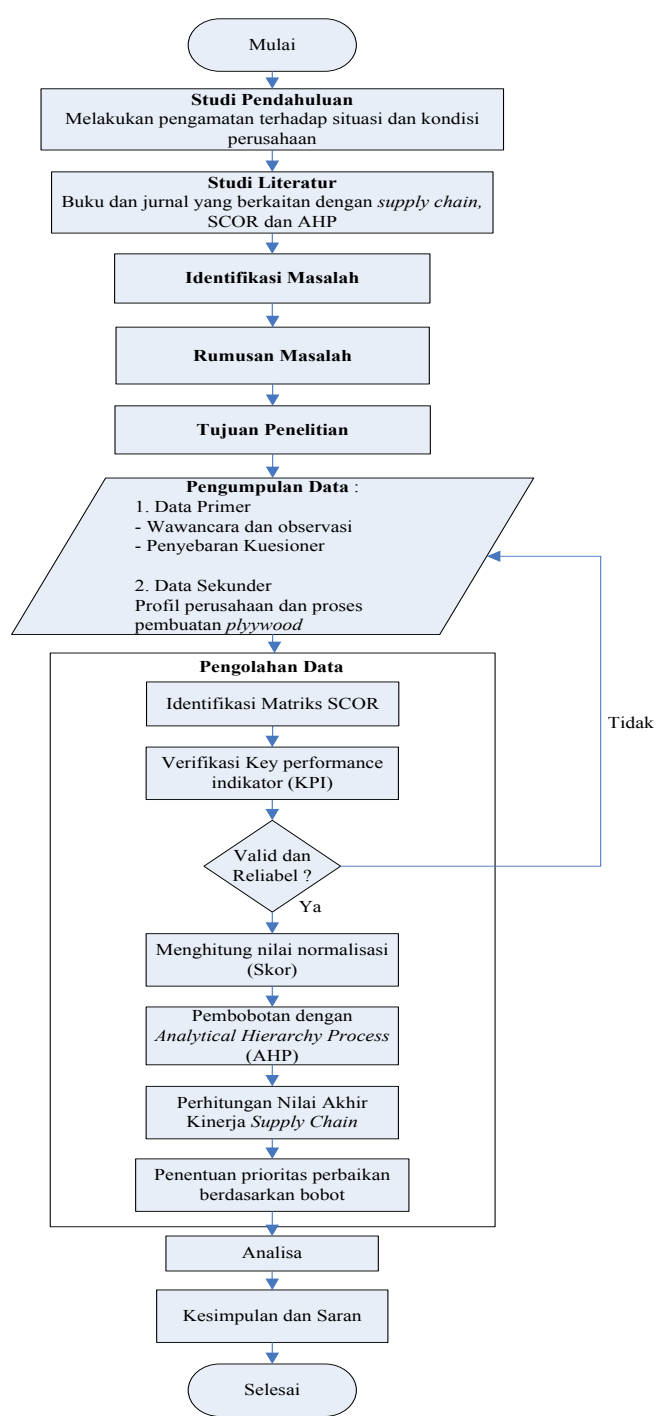

Gambar 2. Flowchart Metode Penelitian

\section{Hasil dan Pembahasan}

Dalam penelitian ini, selain data gambaran perusahaan, data juga dikumpulkan dalam bentuk kuesioner penilian kinerja aliran supply chain. Pengolahan dalam penelitian ini secara umum terdiri dari beberapa tahap, yaitu mengidentifikasi matrik SCOR, pengujian validitas dan reliabilitas kuesioner, perhitungan nilai normalisasi (skor), pembobotan KPI dengan metode Analytical Hierarchy Process (AHP), dan perhitungan total nilai kinerja supply chain. Tahapan terakhir adalah melakukan analisis terhadap indikator yang memiliki bobot terendah pada setiap variabelnya.

\section{Identifikasi Matrik SCOR}

Matrik SCOR terdiri dari tiga level yaitu, level pertama disebut proses yang terdiri dari proses SCOR (Plan, source, make, deliver dan return). Level kedua disebut dimensi yang terdiri dari atribut kinerja antara lain reliability, responsiveness, agility, cost, dan asset. Level ketiga yaitu key performance indikator berisikan indikator-indikator supply chain yang sesuai dengan kondisi perusahaan.

Tabel 7 Identifikasi Matrik Tiap Level Berdasarkan Keadaan Perusahaan

\section{Pengujian Validitas dan Reliabilitas}

Uji validitas dilakukan untuk mengetahui sejauh mana responden mengerti terhadap pertanyaanpertanyaan yang terdapat pada kuesioner, sedangkan uji realibilitas bertujuan untuk mengetahui kehandalan dari kuesioner tersebut. Pengujian dilakukan dengan menggunakan software SPSS 17.0.

\begin{tabular}{|c|c|c|c|}
\hline \multirow{2}{*}{ Pertanyaan } & \multirow{2}{*}{ R hitung } & \multirow{2}{*}{$\begin{array}{c}\mathbf{R} \\
\text { tabel }\end{array}$} & \multirow{2}{*}{$\begin{array}{c}\text { Validitas } \\
\mathbf{R} \text { hitung }>\mathbf{R} \text { tabel }\end{array}$} \\
\hline & & & \\
\hline 1 & 0,561 & 0,514 & Valid \\
\hline 2 & 0,428 & 0,514 & Tidak valid \\
\hline 3 & $.0,594$ & 0,514 & Valid \\
\hline 4 & 0,561 & 0,514 & Valid \\
\hline 5 & 0,516 & 0,514 & Valid \\
\hline 6 & 0,516 & 0,514 & Valid \\
\hline 7 & 0,658 & 0,514 & Valid \\
\hline 8 & 0,594 & 0,514 & Valid \\
\hline 9 & 0,516 & 0,514 & Valid \\
\hline 10 & 0,640 & 0,514 & Valid \\
\hline 11 & 0,594 & 0,514 & Valid \\
\hline 12 & 0,516 & 0,514 & Valid \\
\hline 13 & 0,516 & 0,514 & Valid \\
\hline 14 & 0,414 & 0,514 & Tidak valid \\
\hline 15 & 0,594 & 0,514 & Valid \\
\hline 16 & 0,594 & 0,514 & Valid \\
\hline 17 & 0,352 & 0,514 & Tidak valid \\
\hline 18 & 0,258 & 0,514 & Tidak valid \\
\hline 19 & 0,617 & 0,514 & Valid \\
\hline 20 & 0,516 & 0,514 & Valid \\
\hline 21 & 0,561 & 0,514 & Valid \\
\hline 22 & 0,535 & 0,514 & Valid \\
\hline 23 & 0,623 & 0,514 & Valid \\
\hline 24 & 0,517 & 0,514 & Valid \\
\hline 25 & 0,420 & 0,514 & Tidak valid \\
\hline \multicolumn{4}{|l|}{ Total : 25} \\
\hline \multicolumn{4}{|l|}{ Valid: 5} \\
\hline Tidak valid & & & \\
\hline
\end{tabular}

Berdasarkan pengolahan dari pernyataanpernyataan yang valid, didapat nilai Cronbach's Alpha sebesar 0,891. Hal ini menunjukkan bahwa kuesioner reliabel karena jika nilai Cronbach's Alpha semakin mendekati 1, maka semakin reliabel kuesioner tersebut.

Tabel 9 Reliability Statistics

\begin{tabular}{|c|c|c|}
\hline $\begin{array}{c}\text { Cronbach's } \\
\text { Alpha }\end{array}$ & $\begin{array}{c}\text { Cronbach's Alpha } \\
\text { Based on } \\
\text { Standardized Items }\end{array}$ & N of Items \\
\hline 0,891 & 0,912 & 20 \\
\hline
\end{tabular}

(Sumber : Pengolahan Data, 2016)

\section{Menghitung Nilai Normalisasi (Skor)}

Proses normalisasi dilakukan dengan rumus normalisasi Snorm De Boer. Setiap indikator akan 
dilakukan penilaian normalisasi dimana Si merupakan nilai aktual. Nilai aktual didapatkan dari rata-rata nilai pada angket yang telah disebarkan sebelumnya dapat dilihat pada Smin adalah nilai kinerja terendah $=0$, dan Smax adalah nilai kinerja tertinggi $=100$ :

$$
\begin{aligned}
& \text { Snorm (skor) }=\frac{S i-S \min }{S \max -S \min } \times 100 \text { atau } \\
& \text { Snorm (skor) }=\frac{\text { skor }-0}{100-0} \times 100 \\
& \text { perhitungan nilai skor : }
\end{aligned}
$$$$
\text { Perencanaan kebutuhan bahan baku (sP2.1) }
$$

Skor $(\mathrm{sP} 2.1)=\frac{72,69-0}{100-0} \times 100=72,69$

\begin{tabular}{|c|c|c|c|}
\hline \begin{tabular}{|l|}
$\begin{array}{l}\text { Proses } \\
\text { (Level 1) }\end{array}$ \\
\end{tabular} & $\begin{array}{l}\text { Dimensi } \\
\text { (Level 2) }\end{array}$ & $\begin{array}{c}\text { Key Performance Indicator } \\
\text { (Level 3) }\end{array}$ & Skor \\
\hline \multirow{5}{*}{$\begin{array}{l}\text { (P) } \\
\text { Plan }\end{array}$} & \multirow{5}{*}{$\begin{array}{l}\text { (P.2) } \\
\text { Responsive } \\
\text { ness }\end{array}$} & $\begin{array}{l}\text { (P.1.1) Perencanaan } \\
\text { kebutuhan bahan baku }\end{array}$ & 72,69 \\
\hline & & $\begin{array}{l}\text { (P.1.2) Perencanaan } \\
\text { kebutuhan distribusi }\end{array}$ & 70,00 \\
\hline & & $\begin{array}{l}\text { (P.1.3) Jangka waktu } \\
\text { penjadwalan produksi }\end{array}$ & 82,81 \\
\hline & & $\begin{array}{l}\text { (P.1.4) Jangka waktu } \\
\text { mengidentifikasi produk baru }\end{array}$ & 76,06 \\
\hline & & $\begin{array}{l}\text { (P.1.5) Perencanaan proses } \\
\text { pengadaan bahan baku }\end{array}$ & 69,06 \\
\hline \multirow{4}{*}{$\begin{array}{l}\text { (S) } \\
\text { Source }\end{array}$} & \multirow{2}{*}{$\begin{array}{l}\text { (S.1) } \\
\text { Reliability }\end{array}$} & $\begin{array}{l}\text { (S.1.1) Pemenuhan bahan } \\
\text { baku }\end{array}$ & 60,94 \\
\hline & & $\begin{array}{l}\text { (S.1.2) Kehandalan supplier } \\
\text { dalam pengiriman bahan baku }\end{array}$ & 69,38 \\
\hline & $\begin{array}{l}\text { (S.2) } \\
\text { Responsive } \\
\text { ness }\end{array}$ & $\begin{array}{l}\text { (S.2.1) Penanganan bahan } \\
\text { baku yang cacat }\end{array}$ & 76,75 \\
\hline & (S.3) Agility & $\begin{array}{l}\text { (S.3.1) Waktu tunggu untuk } \\
\text { pemenuhan bahan baku }\end{array}$ & 52,81 \\
\hline \multirow{5}{*}{$\begin{array}{l}\text { (M) } \\
\text { Make }\end{array}$} & \multirow{3}{*}{$\begin{array}{l}\text { (M.1) } \\
\text { Reliability }\end{array}$} & $\begin{array}{l}\text { (M.1.1) Penanganan produk } \\
\text { cacat atau turun grade }\end{array}$ & 71,56 \\
\hline & & $\begin{array}{l}\text { (M.1.2) Penyelesaian } \\
\text { produksi sesuai jadwal }\end{array}$ & 84,50 \\
\hline & & $\begin{array}{l}\text { (M.1.3) Ketanggapan } \\
\text { memproduksi pesanan } \\
\text { konsumen yang bervariasi }\end{array}$ & 82,38 \\
\hline & \multirow{2}{*}{$\begin{array}{l}\text { (M.2) } \\
\text { Responsive } \\
\text { ness }\end{array}$} & $\begin{array}{l}\text { (M.2.1) Penanganan } \\
\text { kerusakan mesin produksi }\end{array}$ & 83,13 \\
\hline & & (M.2.2) Kinerja karyawan & 78,00 \\
\hline \multirow{5}{*}{$\begin{array}{l}\text { (D) } \\
\text { Deliver }\end{array}$} & $\begin{array}{l}\text { (D.1) } \\
\text { Reliability }\end{array}$ & $\begin{array}{l}\text { (D.1.1) Kualitas pengiriman } \\
\text { produk }\end{array}$ & 81,25 \\
\hline & \multirow{2}{*}{$\begin{array}{l}\text { (D.2) } \\
\text { Responsive } \\
\text { ness }\end{array}$} & $\begin{array}{l}\text { (D.2.1) Pengiriman produk } \\
\text { tepat waktu }\end{array}$ & 75,63 \\
\hline & & $\begin{array}{l}\text { (D.2.2) Jumlah pengiriman } \\
\text { bahan baku yang tepat }\end{array}$ & 70,94 \\
\hline & \multirow{2}{*}{$\begin{array}{l}\text { (D.3) } \\
\text { Agility }\end{array}$} & $\begin{array}{l}\text { (D.3.1) Fleksibilitas } \\
\text { pengiriman terhadap } \\
\text { penurunan permintaan }\end{array}$ & 81,63 \\
\hline & & $\begin{array}{l}\text { (D.3.2) Fleksibilitas } \\
\text { pengiriman terhadap } \\
\text { peningkatan permintaan }\end{array}$ & 84,38 \\
\hline \multirow{3}{*}{$\begin{array}{l}(\mathrm{R}) \\
\text { Return }\end{array}$} & $\begin{array}{l}\text { R.1) } \\
\text { Reliability }\end{array}$ & $\begin{array}{l}\text { (R.1.1) Jumlah komplain dari } \\
\text { konsumen }\end{array}$ & 70,63 \\
\hline & \multirow{2}{*}{$\begin{array}{l}\text { (R.2) } \\
\text { Responsive } \\
\text { ness }\end{array}$} & $\begin{array}{l}\text { (R.2.1) Persentasi } \\
\text { penggantian produk cacat } \\
\text { dengan kuantitas dan jenis } \\
\text { yang tepat }\end{array}$ & 84,88 \\
\hline & & $\begin{array}{l}\text { (R.2.2)Penanganan dari } \\
\text { komplain yang diajukan } \\
\text { konsumen }\end{array}$ & 82,50 \\
\hline
\end{tabular}

Tabel 10 Rekapitulasi Nilai Normalisasi (Skor) Key Performance Indicator

(Sumber : Pengolahan Data, 2016)

\section{Pembobotan dengan Analytical Hierarchy Process (AHP)}

Pemberian bobot nilai terhadap setiap variabel dan indikator dilakukan dengan menggunakan metode Analytical Hierarchy Process (AHP). Gambar 3 menunjukkan struktur hirarki (AHP) kinerja aliran supply chain.

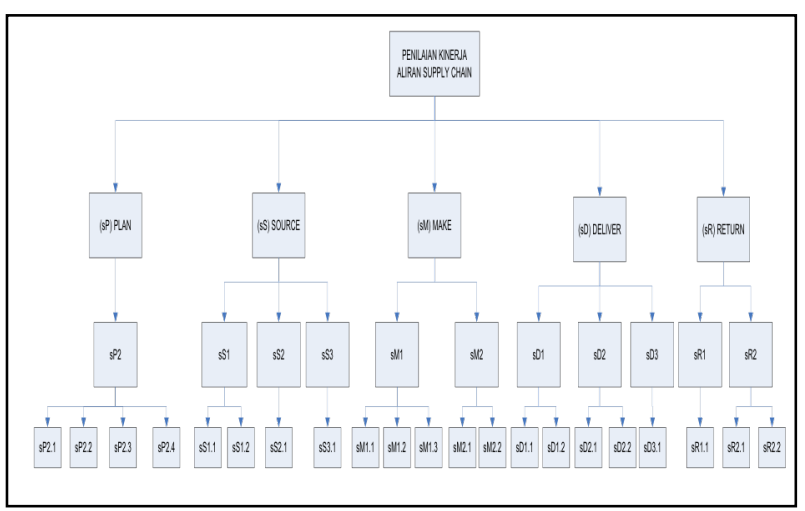

Gambar 3. Struktur Hierarki Penilaian Aliran Kinerja Supply chain

Perhitungan bobot pada AHP dilakukan dalam beberapa tahapan yaitu memberikan nilai berpasangan pada masing-masing kriteria, melakukan sintesa prioritas perbandingan berpasangan, dan menghitung rasio konsistensi supply chain. Dengan rekapitulasi sebagai berikut

Tabel 11 Rekapitulasi Nilai Bobot pada Tiap Level di PT.

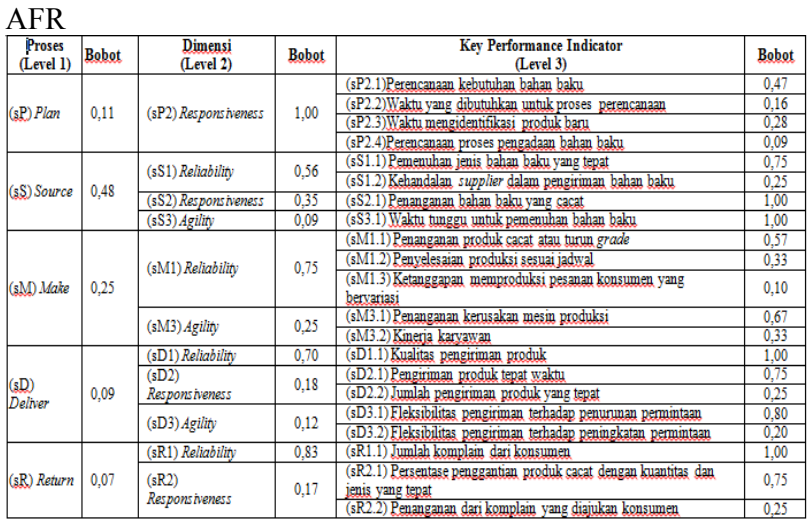

(Pengolahan Data, 2016)

\section{Perhitungan Nilai Akhir Kinerja Supply chain}

Perhitungan nilai akhir kinerja aliran supply chain dilakukan dengan cara mengalikan setiap skor normalisasi yang telah didapatkan dari rumus normalisasi snorm de boer dengan bobot tiap-tiap ruang lingkup key performance Indicator, dimensi, dan proses. Sedangkan nilai Total KPI didapatkan dengan cara menjumlahkan setiap nilai kinerja yang berada pada satu matrik.

Nilai kinerja sP2.1 = skor $\mathrm{x}$ bobot 

dalam bidang Teknik Industri

$$
=72,69 \times 0,47=34,16
$$

Nilai Total KPI Responsiveness Plan

$=\mathrm{sP} 2.1_{\text {nilai kinerja }}+\mathrm{sP} 2.2_{\text {nilai kinerja }}+\mathrm{sP} 2.3$ nilai kinerja $+\mathrm{sP} 2.4$

$=34,16+13,25+21,3+6,22=74,93$

Tabel 12 Rekapitulasi Nilai Kinerja Key Performance Indicator

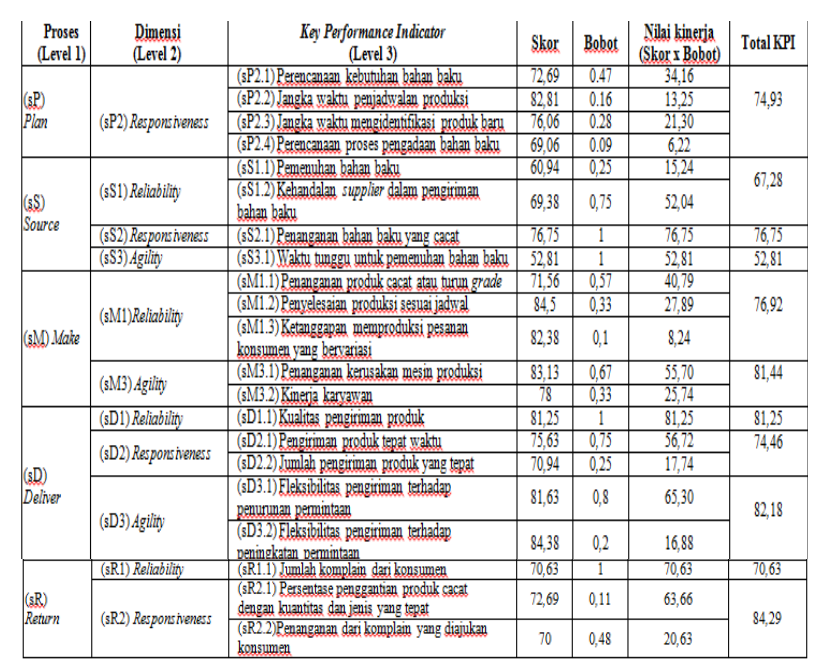

Setelah melakukan perhitungan nilai kinerja key perrmance indicator maka tahapan selanjutya adalah melakukan perhitungan nilai kinerja pada dimensi (level 2) dengan cara mengalikan nilai total akhir KPI (level 3) dengan bobot dimensi (Level 2).

Nilai kinerja $\mathrm{sP} 2=$ Skor $_{\text {(total KPI level 3) }} \mathrm{x}$ Bobot sP2

$$
=74,93 \times 1,00=74,93
$$

Nilai Total KPI Responsiveness Plan $=74,93$

\begin{tabular}{|c|c|c|c|c|c|}
\hline $\begin{array}{l}\text { Proses } \\
\text { (Level })\end{array}$ & $\begin{array}{l}\text { Dimensi } \\
\text { (Level 2) }\end{array}$ & $\begin{array}{c}\text { Sko } \\
\mathbf{r}\end{array}$ & Bobot & $\begin{array}{c}\text { Nilai } \\
\text { kinerja } \\
\text { (Skor x } \\
\text { Bobot) } \\
\end{array}$ & $\begin{array}{c}\text { Total } \\
\text { tiap } \\
\text { dimen } \\
\text { si } \\
\end{array}$ \\
\hline $\begin{array}{l}(\mathrm{P}) \\
\text { Plan }\end{array}$ & $\begin{array}{l}\text { (P.2) } \\
\text { Responsivene } \\
\text { ss }\end{array}$ & $\begin{array}{c}73,9 \\
8\end{array}$ & 1,00 & 73,98 & 73,98 \\
\hline \multirow{3}{*}{$\begin{array}{l}(\mathrm{S}) \\
\text { Sourc } \\
e\end{array}$} & $\begin{array}{l}\text { S.1) } \\
\text { Reliability }\end{array}$ & $\begin{array}{c}67,2 \\
7 \\
\end{array}$ & 0,56 & 37,67 & \multirow{3}{*}{69,29} \\
\hline & $\begin{array}{l}\text { (S.2) } \\
\text { Responsivene } \\
\text { ss }\end{array}$ & $\begin{array}{c}76,7 \\
5\end{array}$ & 0,35 & 26,86 & \\
\hline & (S.3) Agility & $\begin{array}{c}52,8 \\
1 \\
\end{array}$ & 0,09 & 4,75 & \\
\hline \multirow{2}{*}{$\begin{array}{l}(\mathrm{M}) \\
\text { Make }\end{array}$} & $\begin{array}{l}\text { (M.1) } \\
\text { Reliability }\end{array}$ & $\begin{array}{c}76,9 \\
1\end{array}$ & 0,75 & 57,68 & \multirow[b]{2}{*}{78,04} \\
\hline & $\begin{array}{l}\text { (M.2) } \\
\text { Responsivene } \\
\text { ss }\end{array}$ & $\begin{array}{c}81,4 \\
4\end{array}$ & 0,25 & 20,36 & \\
\hline \multirow{3}{*}{$\begin{array}{l}\text { (D) } \\
\text { Deliv } \\
\text { er }\end{array}$} & $\begin{array}{l}\text { (D.1) } \\
\text { Reliability }\end{array}$ & $\begin{array}{c}81,2 \\
5\end{array}$ & 0,57 & 46,31 & \multirow{3}{*}{79,49} \\
\hline & $\begin{array}{l}\text { (D.2) } \\
\text { Responsivene } \\
\text { ss }\end{array}$ & $\begin{array}{c}74,4 \\
6\end{array}$ & 0,28 & 20,85 & \\
\hline & (D.3) Agility & 82,1 & 0,15 & 12,33 & \\
\hline
\end{tabular}

Tabel13 Rekapitulasi Nilai Kinerja Dimensi (Level 2)

\begin{tabular}{|c|c|c|c|c|c|}
\hline & & 8 & & & \\
\hline \multirow{2}{*}{$\begin{array}{l}\text { (R) } \\
\text { Retur } \\
n\end{array}$} & $\begin{array}{l}\text { (R.1) } \\
\text { Reliability }\end{array}$ & $\begin{array}{c}70,6 \\
3\end{array}$ & 0,83 & 58,62 & \multirow[b]{2}{*}{72,95} \\
\hline & $\begin{array}{l}\text { (R.2) } \\
\text { Responsivene }\end{array}$ & $\begin{array}{c}84,2 \\
9\end{array}$ & 0,17 & 14,33 & \\
\hline
\end{tabular}


Tabel 14 Rekapitulasi Nilai Kinerja Akhir

\begin{tabular}{|l|c|c|c|}
\hline \multicolumn{1}{|c|}{ Proses } & Skor & Bobot & $\begin{array}{c}\text { Nilai Akhir } \\
\text { (Skor x Bobot) }\end{array}$ \\
\hline (P) Plan & 73,98 & 0,11 & 8,14 \\
\hline (S) Source & 69,29 & 0,48 & 33,26 \\
\hline (M) Make & 78,04 & 0,25 & 19,51 \\
\hline $\begin{array}{l}\text { (D) } \\
\text { Deliver }\end{array}$ & 79,49 & 0,09 & 7,15 \\
\hline $\begin{array}{l}\text { (R) } \\
\text { Return }\end{array}$ & 72,95 & 0,07 & 5,11 \\
\hline \multicolumn{3}{|c|}{ Total } \\
\hline
\end{tabular}

Perhitungan kinerja tiap level dilakukan dengan mengalikan skor normalisasi dengan bobot masingmasing dengan menggunakan AHP. Hasil rekapitulasi kinerja aliran supply chain di PT. AFR menunjukkan nilai total kinerja aliran supply chain sebesar 73,33 kategori good dengan bobot terendah pada proses source 69,29 dengan aktegori average.

\section{Penentuan Prioritas Perbaikan Berdasarkan Bobot}

Setelah mengetahui nilai kinerja aliran supply chain dan nilai bobot masing-masing level di PT. AFR, maka proses selanjutnya adalah menentukan indikatorindikator yang perlu diperbaiki berdasarkan bobot nilai terendah pada masing-masing proses. Tabel berikut menunjukkan indikator-indikator yang memiliki bobot terendah.

Tabel 14 Rekapitulasi Indikator dengan Bobot Terendah

\begin{tabular}{|l|l|c|}
\hline Proses & \multicolumn{1}{|c|}{ Indikator } & Bobot \\
\hline Plan & $\begin{array}{l}\text { (P.1.1) Perencanaan kebutuhan bahan } \\
\text { baku }\end{array}$ & 0,11 \\
\cline { 2 - 3 } & $\begin{array}{l}\text { (P.2.2) Jangka waktu mengidentifikasi } \\
\text { produk baru }\end{array}$ & 0,09 \\
\hline \multirow{2}{*}{ Source } & $\begin{array}{l}\text { (P.3.1) Perencanaan proses pengadaan } \\
\text { bahan baku }\end{array}$ & 0,07 \\
\hline Make & $\begin{array}{l}\text { S.1.2) Kehandalan supplier dalam } \\
\text { pengiriman bahan baku }\end{array}$ & 0,25 \\
\hline \multirow{2}{*}{ Deliver } & $\begin{array}{l}\text { (M.1.3) Ketanggapan memproduksi } \\
\text { pesanan konsumen yang bervariasi }\end{array}$ & 0,10 \\
\cline { 2 - 3 } & $\begin{array}{l}\text { (M.2.2) Kinerja karyawan } \\
\text { tepat }\end{array}$ & 0,33 \\
\hline \multirow{2}{*}{ Return } & $\begin{array}{l}\text { (D.3.2) Fleksibilitas pengiriman pengiriman produk yang } \\
\text { terhadap peningkatan permintaan }\end{array}$ & 0,25 \\
\hline $\begin{array}{l}\text { (R.2.2) Penanganan dari komplain yang } \\
\text { diajukan konsumen }\end{array}$ & 0,20 \\
\hline
\end{tabular}

\section{Kesimpulan}

Nilai total kinerja aliran supply chain di PT. Asia Forestama Raya adalah 73,33 yang berarti kinerja aliran supply chain berada pada klasifikasi Good dengan nilai kinerja pada masing-masing proses SCOR adalah plan 74,93 dengan kategori Good, source 69,29 dengan kategori Average, make 78,05 kategori Good, deliver 80,13 kategori Good dan return 72,95 kategori Good.
Beberapa perbaikan yang dilakukan terhadap indikator yang memiliki bobot terendah antara lain : (1) melakukan komunikasi yang lebih baik kepada setiap karyawan dengan mengadakan briefing setiap 3 kali dalam seminggu, (2) menembah supplier yang dapat memenuhi kekurangan bahan baku, (3) perusahaan diharapkan memiliki taman hutan sendiri, (4) melakukan pengkajian terhadap aturan bisnis yang telah dibuat dengan supplier, (5) untuk dapat meningkatkan kinerja karyawan perusahaan diharapkan dapat memberikan reward berupa kenaikan jabatan atau berupa barang/uang kepada karyawan yang memiliki kinerja terbaik, (6) memberikan pelatihan on the job training kepada karyawan yang baru dirotasi, dan (7) memberikan penjelasan kepada konsumen tentang keterlambatan pengiriman produk yang bisa saja terjadi akibat tidak terpenuhinya bahan baku.

\section{DAFTAR PUSTAKA}

Anatan, Lina dan Lena Ellitan. "Supply chain Management Teori dan Aplikasi". Alfabeta, Bandung. 2008.

Ernawati, Dira. "Pengembangan Model Pengukuran Kinerja Supply chain di PT. Indomapan”. Jurnal FTI-UPN 'Veteran' Jawa Timur. 2012.

Handoyo. "Evaluasi Tingkat Fleksibilitas Supply chain”. Majalah Ilmiah Universitas Pembangunan Nasional Veteran Jawa Timur, Surabaya. 2011.

Hanugrani, Nikita, dkk. "Pengukuran Performansi Supply chain dengan Menggunakan Supply chain Operation Reference (SCOR) Berbasis Analytical Hierarchy Procces (AHP) dan Objective Matrix (OMAX)". 2013

Kusrini. "Konsep dan Aplikasi Sistem Pendukung Keputusan". Andi, Yogyakarta. 2007.

Kusuma, Parama Tirta. W. W, dkk. "Perbaikan Kinerja Supply chain Perusahaan Keripik Singkong Berdasarkan Analisis Product Availability". Jurnal Agritech. Vol. 30, No. 2, Mei 2010.

Paul, John. "Transformasi Rantai Suplai Dengan Metode SCOR”. PPM, Jakarta. 2014.

Pujawan, I Nyoman. "Supply chain Management". Guna Widya, Surabaya. 2005.

Siahaya, Willem. "Sukses Supply chain Management Akses Demand Chain Management". In Media, Jakarta. 2013. 
Suharto, Regina, dan Devie. "Analisa Pengaruh

Supply chain Management terhadap

Keunggulan Bersaing dan Kinerja

Perusahaan ". Business Accounting Review.

Vol. 1. No 2, 2013.

Suliantoro, Hery, dan Dewi Nugrahani.

"Pengukuran dan Evaluasi Kinerja Supply

chain Balance Scorecard-Analytical

Network Process (BSC-ANP) di PT.

Madubaru Yogyakarta". Prosiding SNST

Ke-6. 2015 